\title{
Functionalized biopolymer particles enhance performance of a tissue-protective peptide under proteolytic and thermal stress
}

\author{
Kevin Dooley $^{1}$, Julie Devalliere ${ }^{1}$, Basak E. Uygun ${ }^{1}, \&$ Martin L. Yarmush ${ }^{1,2 *}$ \\ ${ }^{1}$ Center for Engineering in Medicine, Massachusetts General Hospital, Harvard Medical School, Shriners \\ Hospitals for Children, Boston, Massachusetts, USA \\ ${ }^{2}$ Department of Biomedical Engineering, Rutgers University, Piscataway, New Jersey, USA \\ ${ }^{*}$ Corresponding author
}




\title{
SUPPORTING INFORMATION
}

Oligonucleotides for Plasmid Construction

\author{
Sequence $\left(5^{\prime} \rightarrow 3^{\prime}\right)$ \\ $\begin{array}{ll}\text { [VPGVG]5_F } & \text { CGTGGGTGTTCCGGGCGTAGGTGTCCCAGGTGTGGGCGTACCGGGCGTTGGTGTTCC } \\ & \text { TGGTTCGGCGTGCCGGG }\end{array}$ \\ [VPGVG]5_F CGGCACGCCGACACCAGGAACACCAACGCCCGGTACGCCCACACCTGGGACACCTAC \\ GCCCGGAACACCCACGCC
}

ARA290_F CCAGGAACAGCTGGAACGTGCGCTGAACAGCAGCGG

ARA290_R GCTGCTGTTCAGCGCACGTTCCAGCTGTTCCTGGCC

Myc_F CGAACAGAAACTGATtAgCGAAGAAGATCTGGG

Myc_R CAgAtCTTCTTCGCtAATCAGTtTCTGTTCGCC

ELP and ARA290-ELP Fusion Protein Primary Sequences

MGQEQLERALNSSGVGVPGVGVPGVGVPGVGVPGVGVPGVGVPGVGVPGVGVPGVGV A-V40 PGVGVPGVGVPGVGVPGVGVPGVGVPGVGVPGVGVPGVGVPGVGVPGVGVPGVGVPG VGVPGVGVPGVGVPGVGVPGVGVPGVGVPGVGVPGVGVPGVGVPGVGVPGVGVPGVG VPGVGVPGVGVPGVGVPGVGVPGVGVPGVGVPGVGVPGVGVPGEQKLISEEDLGY

MGQEQLERALNSSGVGVPGVGVPGVGVPGVGVPGVGVPGVGVPGVGVPGVGVPGVGV PGVGVPGVGVPGVGVPGVGVPGVGVPGVGVPGVGVPGVGVPGVGVPGVGVPGVGVPG VGVPGVGVPGVGVPGVGVPGVGVPGVGVPGVGVPGVGVPGVGVPGVGVPGVGVPGVG VPGVGVPGVGVPGVGVPGVGVPGVGVPGVGVPGVGVPGVGVPGVGVPGVGVPGVGVP GVGVPGVGVPGVGVPGVGVPGVGVPGVGVPGVGVPGVGVPGVGVPGVGVPGVGVPGV A-V120 GVPGVGVPGVGVPGVGVPGVGVPGVGVPGVGVPGVGVPGVGVPGVGVPGVGVPGVGV PGVGVPGVGVPGVGVPGVGVPGVGVPGVGVPGVGVPGVGVPGVGVPGVGVPGVGVPG VGVPGVGVPGVGVPGVGVPGVGVPGVGVPGVGVPGVGVPGVGVPGVGVPGVGVPGVG VPGVGVPGVGVPGVGVPGVGVPGVGVPGVGVPGVGVPGVGVPGVGVPGVGVPGVGVP GVGVPGVGVPGVGVPGVGVPGVGVPGVGVPGVGVPGVGVPGVGVPGVGVPGVGVPGV GVPGVGVPGVGVPGVGVPGVGVPGVGVPGVGVPGVGVPGVGVPGEQKLISEEDLGY

MGVGVPGVGVPGVGVPGVGVPGVGVPGVGVPGVGVPGVGVPGVGVPGVGVPGVGVPG

V40 VGVPGVGVPGVGVPGVGVPGVGVPGVGVPGVGVPGVGVPGVGVPGVGVPGVGVPGVG VPGVGVPGVGVPGVGVPGVGVPGVGVPGVGVPGVGVPGVGVPGVGVPGVGVPGVGVP GVGVPGVGVPGVGVPGVGVPGVGVPGVGVPGEQKLISEEDLGY 
MGVGVPGVGVPGVGVPGVGVPGVGVPGVGVPGVGVPGVGVPGVGVPGVGVPGVGVPG VGVPGVGVPGVGVPGVGVPGVGVPGVGVPGVGVPGVGVPGVGVPGVGVPGVGVPGVG VPGVGVPGVGVPGVGVPGVGVPGVGVPGVGVPGVGVPGVGVPGVGVPGVGVPGVGVP GVGVPGVGVPGVGVPGVGVPGVGVPGVGVPGVGVPGVGVPGVGVPGVGVPGVGVPGV GVPGVGVPGVGVPGVGVPGVGVPGVGVPGVGVPGVGVPGVGVPGVGVPGVGVPGVGV V120 PGVGVPGVGVPGVGVPGVGVPGVGVPGVGVPGVGVPGVGVPGVGVPGVGVPGVGVPG VGVPGVGVPGVGVPGVGVPGVGVPGVGVPGVGVPGVGVPGVGVPGVGVPGVGVPGVG VPGVGVPGVGVPGVGVPGVGVPGVGVPGVGVPGVGVPGVGVPGVGVPGVGVPGVGVP GVGVPGVGVPGVGVPGVGVPGVGVPGVGVPGVGVPGVGVPGVGVPGVGVPGVGVPGV GVPGVGVPGVGVPGVGVPGVGVPGVGVPGVGVPGVGVPGVGVPGVGVPGVGVPGVGV PGVGVPGVGVPGVGVPGVGVPGVGVPGVGVPGEQKLISEEDLGY

ARA290-ELP \& ELP SDS-PAGE

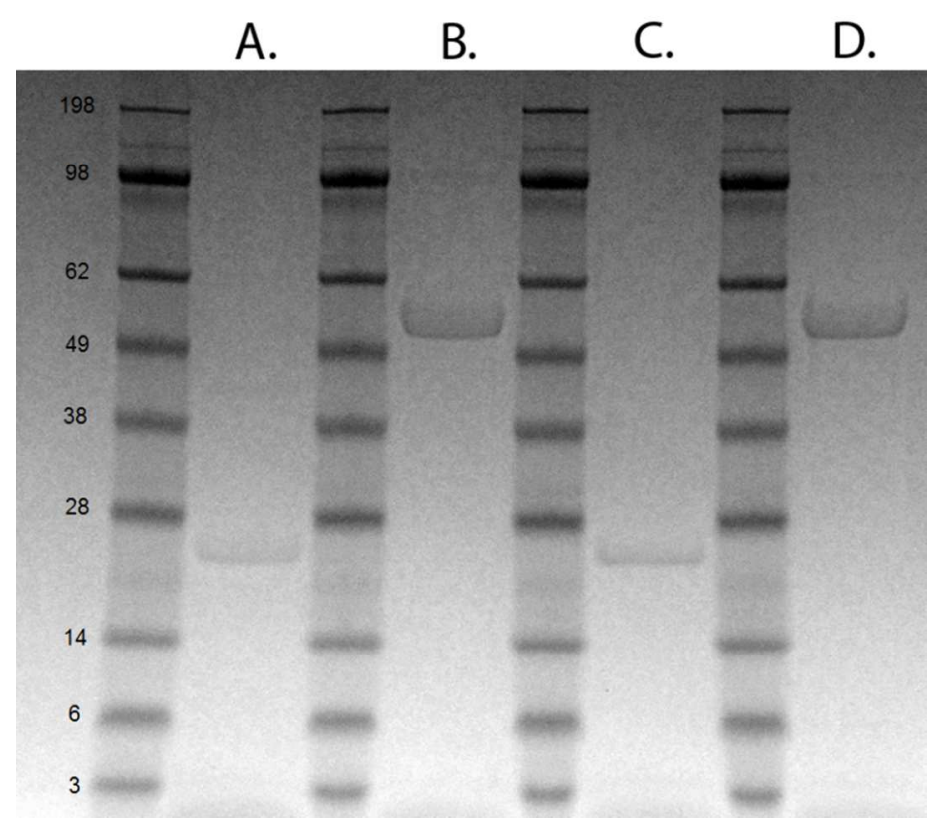

Figure S1. SDS-PAGE analysis for (A.) A-V40, (B.) A-V120, (C.) V40, (D.) V120. Approximately $5 \mu \mathrm{g}$ of protein was loaded on a $4-12 \%$ Bis-Tris gel following 3 rounds of inverse transition cycling. Estimated molecular weights for each construct are 19.3, 52.1, 18.0, and $50.8 \mathrm{kDa}$, respectively. The protein ladder is given in $\mathrm{kDa}$. 

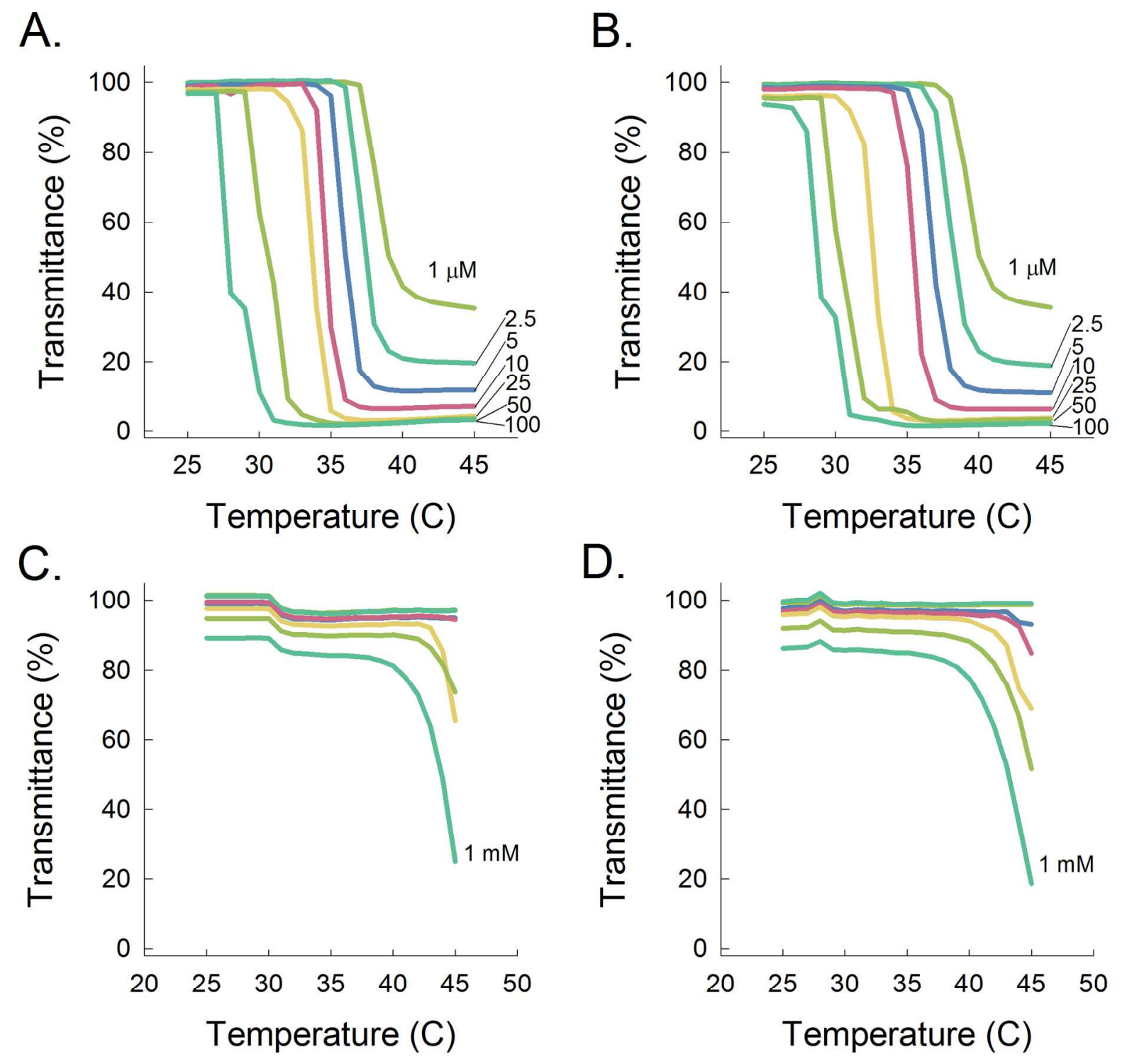

Figure S2. Turbidimetry analysis for (A.) A-V120, (B.) V120, (C.) A-V40, (D.) V40. Percent transmittance readings at $350 \mathrm{~nm}$ were taken in 1 minute intervals as the temperature was raised from 25 ${ }^{\circ} \mathrm{C}$ to $45{ }^{\circ} \mathrm{C}$ over 20 minutes. A-V120 and V120 underwent phase separation at concentrations as low as 1 $\mu \mathrm{M}$ in the temperature range investigated. The shorter biopolymers, A-V40 and V40, did not plateau under these assay conditions, even at substantially higher concentrations $(1 \mathrm{mM})$. All experiments were performed in triplicate and the lines represent the average values. 


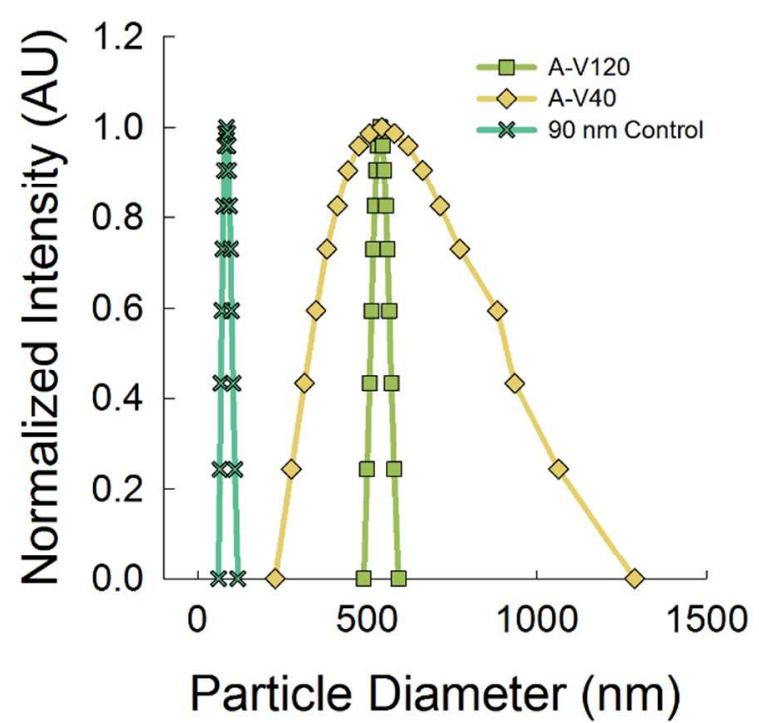

Figure S3. Particle sizing analysis for A-V120 and A-V40. Lognormal particle size distributions are given at $25 \mu \mathrm{M}$ and a $90 \mathrm{~nm}$ size standard. ELP fusions were incubated at $60{ }^{\circ} \mathrm{C}$ for 10 minutes prior to analysis to induce aggregation. Similar trends were observed for V120 and V40 given in Figure 2.

Degradation Assay Sample

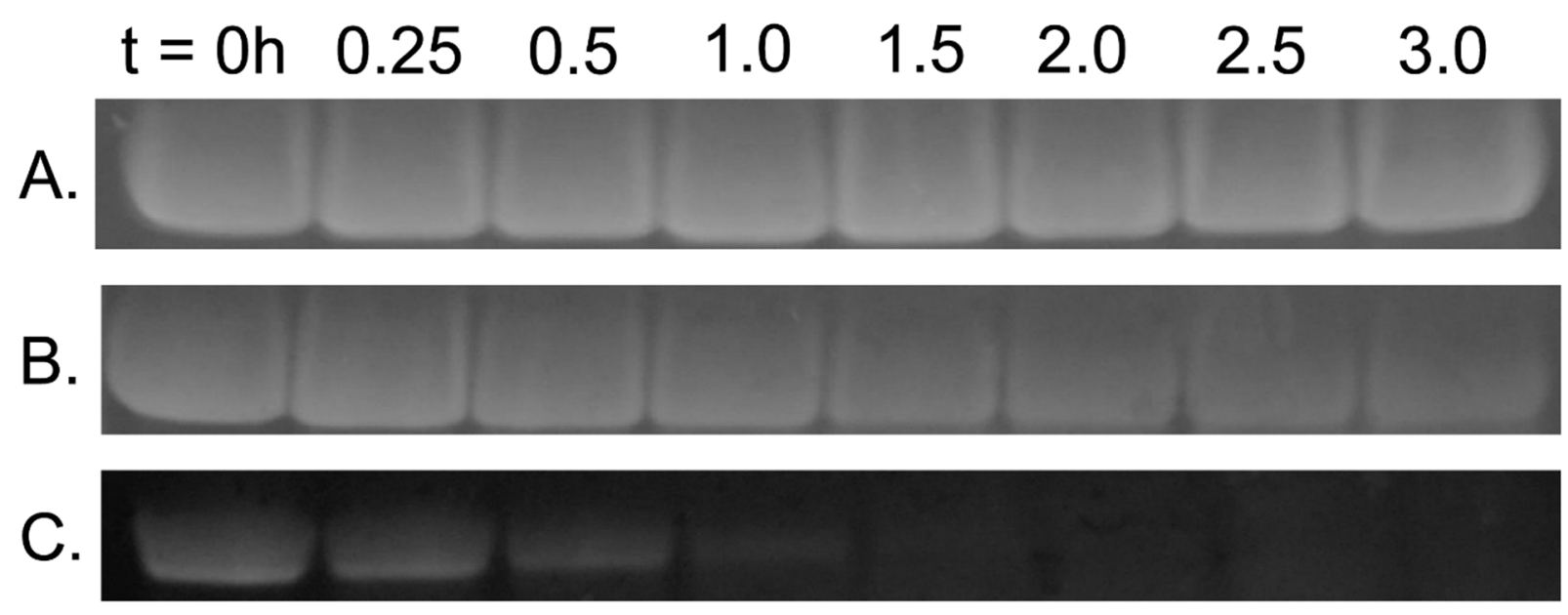

Figure S4. $\sim 5 \mu \mathrm{g}$ of FITC labeled V40 was incubated with lysozyme (A.), collagenase (B.), and elastase (C.) for 3 hours in PBS at $37{ }^{\circ} \mathrm{C}$. Fractions were run on a 4-12\% Bis-Tris gel and imaged on a UVP transilluminator. Cleaved ELP chains appeared as smears below the main band. A blank lane loaded with enzyme only was used to normalize the background intensity. Each band was quantified using pixel intensity processing in ImageJ (Bethesda, MD). A clear drop in band intensity is observed over the 3-hour incubation for both collagenase and elastase. 